\title{
Biological and Economic Evaluation of Alternative Dairy Rationsformulated From Locally Available Feed Ingredients and Agro Industrial by Products at Arbegona and Bensa Districts of SNNPRS, Ethiopia
}

\author{
Meseret Tsegaye $^{1^{*}} \quad$ Bereket Zeleke $^{2} \quad$ Yoseph Mekasha $^{3} \quad$ Solomon Gizaw $^{3}$ \\ 1.Hawassa Agricultural Research Centre, Southern Agricultural Research Institute (SARI), P.O.Box 2126, \\ Hawassa, Ethiopia \\ 2.Southern Agricultural Research Institute (SARI), P.O.Box 06, Hawassa, Ethiopia \\ 3.International Livestock Research Institute (ILRI), P.O.Box 5689, Addis Ababa, Ethiopia \\ P.O.Box, 1294
}

\begin{abstract}
The study was undertaken at Arbegona and Bensa woreda Southern Nations National People Regional State (SNNPRS) Ethiopia, to evaluate the biological and economic evaluation of alternative dairy rations formulated from locally available feed ingredients and agro industrial byproducts under small holder farmers. Twelve second parity and twelve third parity dairy cows with mid lactation mean initial milk yield of $4.36 \pm 0.29$ lit per cow per day and average initial body weight $(243.78 \pm 3.07 \mathrm{~kg})$ was used for this research work. The experiment had three treatments with eight replications by using a randomized complete design. The treatments were; T1, Harvested fresh enset corm (Ensete Ventricosum)) $6 \mathrm{~kg}$ mixed with $1.5 \mathrm{~kg}$ wheat bran, T2,3 kg Sole wheat bran and T3, $3 \mathrm{~kg}$ concentrate mix with comprised $33 \%$ noug seed cake, $66 \%$ wheat bran and $1 \%$ salt. There was significant $(\mathrm{P}<0.05)$ differences in crude protein and acid detergent fiber intakes among treatment groups. The Milk yield have significant difference $(\mathrm{P}<0.05)$ among treatment diets. The daily milk yield increment per supplemented treatment diets in 30 days of experimental period of time (liter/cow/day) was 2.1, 1.93 and 1.5 for T3, T1 and T2 correspondingly, It could be concluded that Holstein Frisian cross breed dairy cows maintained on a basal diet of natural grass supplemented with $1.5 \mathrm{~kg}$ wheat bran and $6 \mathrm{~kg} / \mathrm{day} / \mathrm{cow}$ chopped fresh enset corm have similar milk yield with the supplementation of $3 \mathrm{~kg} / \mathrm{day} / \mathrm{cow}$ concentrate mix for mid lactation Holstein Frisian cross breed dairy cow under farmers management condition; it could be a better strategy to improve the milk yield under small hold farmers with locally available feed resource supplemented with wheat bran is economically feasible at enset production area.
\end{abstract}

Keywords: Locally available, Southern Ethiopia, Supplement, Corm

DOI: $10.7176 / \mathrm{JBAH} / 10-1-04$

Publication date: January $31^{\text {st }} 2020$

\section{Introduction}

Ethiopia, despite its large livestock resource base and an ecological setting suitable for dairy production, is not yet self-sufficient in milk production. Recent report by CSA $(2010 / 11)$ indicated that the total production of cow milk is about 4.06 billion liters, and this translates to an average daily milk production/cow of 1.86 liters/day. The MoA (2012) also reported some improvement in per capita consumption of milk and estimated it at $19.2 \mathrm{~kg}$. As a number of studies (Tilahun et al., 2005; Azage et al., 2006; Belete et al., 2009)indicated, among many factors responsible for low productivity of livestock in the country, the deficiency of feed in terms of quality and quantity often constitutes the major limitation. a growing human population demands more land for crop production (ELDMPS 2007). The main reasons for shortage of feed in Ethiopia are related to shrinkage of grazing lands as a result of expansion of arable cropping and the low contribution of improved forage as livestock feed (CSA 2010). On the other hand, although arable farming has resulted in enormous quantity of crop residue, its utilization is limited due to poor quality. Supplementation of low quality feed resource with concentrate is far from the reach of small holders due to lack of access and escalating price (Belete et al., 2009; Muingaet al., 1992; Lemma, 1993). The goal of any feeding program is to provide the correct amount and balance of nutrients to animals at proper time to achieve the desired level of performance and profitability (Adugna, 2008).

This has remained a great setback to the dissemination of concentrate based feeding packages for the last few decades. Research, therefore, has to be geared towards developing practical on-farm supplementation strategies that could possibly rule out or at least partially replace the use of concentrates by smallholder farmers locally available feed resources mix with agro industrial by products. In this regard, there are opportunities that could be exploited to improve the situation in both smallholder rural system and medium-scale per-urban/urban dairies. Formulating balanced and cost effective rations from locally available feed ingredients could alleviate the feed problem. Moreover, through formulating balanced rations, minimum cost-maximum response could be 
obtained for a certain level of production. Therefore, this study was conducted the biological and economic evaluation of alternative dairy rations formulated from locally available feed ingredients and agro industrial by products under small holder farmers.

\section{Material and methods}

\subsection{Study area}

The study was carried out in two districts (Arbegona and Bensa) of Sidama zone of southern Ethiopia. Arbegona and Bensa woredas'are two of the 19 weredas' of Sidama zone which are located at the eastern part of the zone. Arbegopna woreda is located at a distance of $77 \mathrm{~km}$ from Hawassa, the capital city of SNNPR and $350 \mathrm{~km}$ from Addis Ababa. The wereda has Dega (95\%) and Weynadega (5\%) agro-ecological characteristics with mean annual rainfall $2100 \mathrm{~mm}$, mean annual temperature $14.5^{\circ} \mathrm{C}$ and altitude $3150 \mathrm{~m}$.a.s.l. according to wereda BOARD (2016/17). Bensa Woreda located at the distance of $142 \mathrm{~km}$ from Hawassa and $415 \mathrm{~km}$ from Addis Ababa, The woreda has Dega (47\%), Weynadega (35\%) and Derek woynadega (18\%) agro-ecological characteristics with mean annual rainfall $1150 \mathrm{~mm}$, mean annual temperature $21.5{ }^{\circ} \mathrm{C}$ and average altitude 1775 m.a.s.l. according to wereda BOARD (2017)

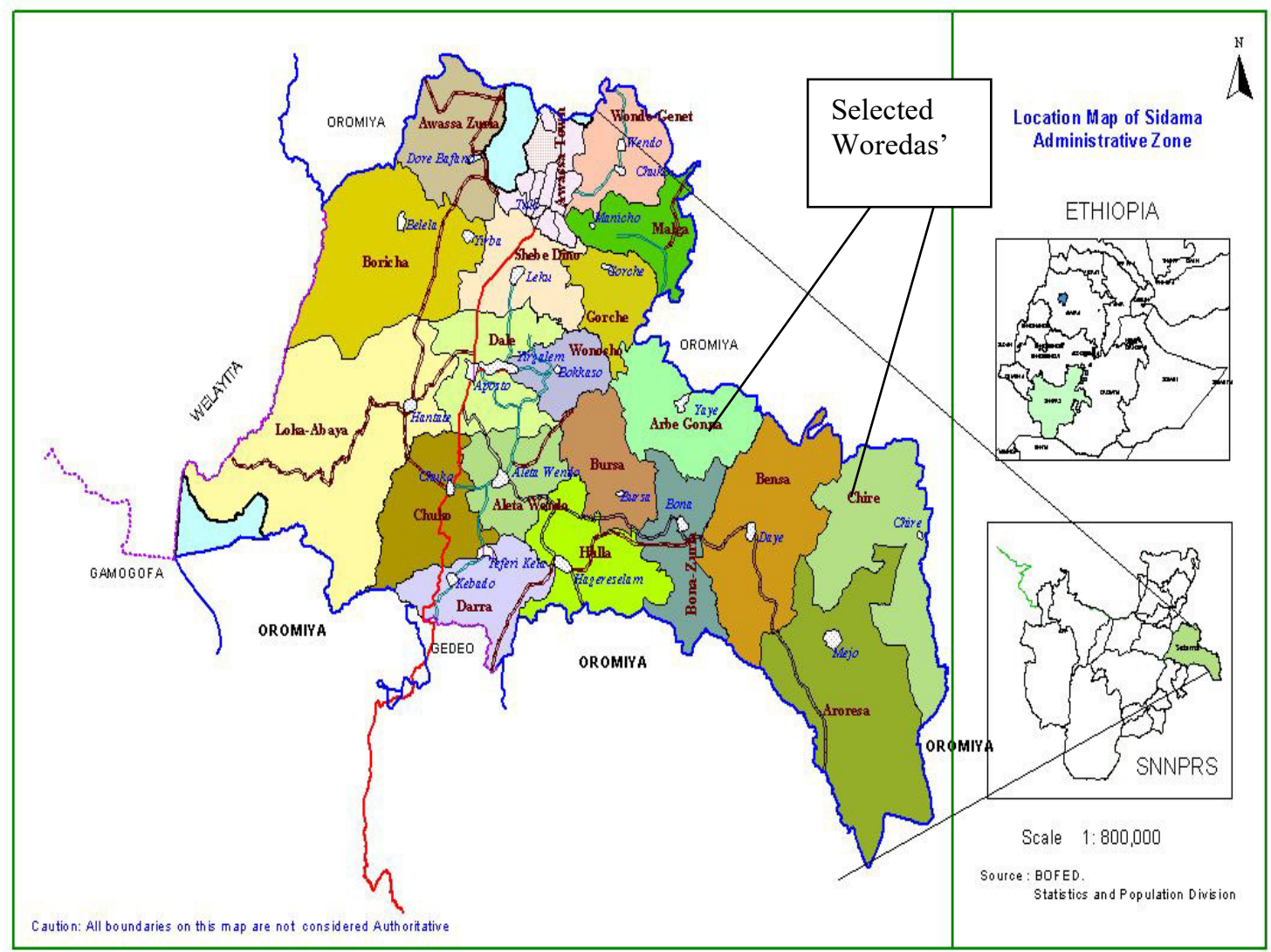

Source, BOFED, (2012)

Fig 1: map of Sidama zone

\subsection{Sampling procedure}

The districts were selected based on their potential for dairy and better experience in cross-breed dairy production. In each district, two villages were selected purposively based on the availability of cross bred dairy cows and accessibility. This was followed by establishment of sampling frame where a list of households with crossbred dairy cows at mid stage of lactation and who were willing to participate in the study was collected. Thus, from the list of households who meet the criteria described above, six households were selected per village randomly for the study. The number of crossbred dairy cows included in the study was 24 (12 per district, 6 per village and 1 per farmer).

Before commencing the study a rapid assessment on types of frequent feeds utilized by farmers in the selected woredas'; milking practice, housing and common types of supplements was conducted through focus group discussion, informant discussion and previous Hawassa agricultural livestock research work process survey in 2015/16. A total of 60 farmers were participated in group discussion, 10 farmers in one group and 30 farmers per district, livestock and fishery office large ruminant and forage experts were participated in both 
woredas on informant discussion.

Preparation of Experimental Diets

Table 1.Livestock feed resources in Bensa and Arbegona woreda

\begin{tabular}{lllllll}
\hline Rank & $\begin{array}{l}\text { Cereal } \\
\text { Crop } \\
\text { residues }\end{array}$ & $\begin{array}{l}\text { Pulse and oil } \\
\text { crop } \\
\text { residues }\end{array}$ & $\begin{array}{l}\text { Natural } \\
\text { pasture }\end{array}$ & $\begin{array}{l}\text { Non- } \\
\text { conventional } \\
\text { feeds }\end{array}$ & $\begin{array}{l}\text { Cultivated } \\
\text { forage crop }\end{array}$ & Root crops \\
\hline 1 & Wheat & Bean & Dominantly & House left over & $\begin{array}{l}\text { Elephant } \\
\text { Desho }\end{array}$ & $\begin{array}{l}\text { Enset part } \\
\text { Sweet potato leaf }\end{array}$ \\
2 & Barley & Pea & & Alfalfa & \\
3 & Maize & & & Vetch & \\
4 & Teff, & & & Tree Lucerne & \\
5 & & & & & & \\
\hline
\end{tabular}

Dairy cow rations were formulated by taking locally available feed resources as main ingredients in such a way that the formulated ration was assumed to fully meet the requirement for major nutrients of target animals as described in ARC (1990).

\subsection{Management of Experimental Animals}

The study was conducted under farm conditions, using cross breed mid lactating dairy cows of dairy producers. The trial was implemented under farmer's management with full follow-up by trained enumerators. All 24 farmers have dairy cow barn, with waterier and feeder. The experimental cows' offered the basal diet natural fresh harvested grass ad labium and the supplement was offered by dividing the proposed daily feed supplement in to two parts in the morning at 6: AM and in the afternoon at 6: PM, the house was cleaned daily in the morning before they milking their cow. All the cows were been drenched with broad-spectrum anti-helminthes (Albendazole2500mg) prior to the start of the experiment. All animals were within a close supervision by veterinarians. All the farmers' daily routine activities were continued during the experiment period. Milking was performed by the farmers. Before milking, calves were allowed to suckle for about 1 minute to initiate milk let down and after milking for the remaining milk. Trained enumerators were monitor and supervise whether farmers are practicing the data recording properly.

\subsection{Treatments and Experimental design}

The dietary treatments were formulated from locally available feed staffs, farmers practiced and feed for cross breed or local breed dairy cow Enset corm (Ensete Ventricosum)),supplementation was practiced in both woredas' it was explained in the survey result livestock feed resources (Table 1) as a supplement, wheat bran and concentrate mix. Treatment diets were used as supplement while harvested fresh natural grass was a basal diet. To use enset corm first the external parts was removed by peeling and chopped and by weighing the daily recommended level was given additionally wheat bran was given as a supplement. Enset corm have high energy $(17.1 \mathrm{MJ} / \mathrm{kg} \mathrm{DM}$ ) and low protein (3.5\% CP/kg DM) (Ajebu N. 2008a). To improve the protein limitation wheat bran $(17.31 \%$ CP) was used as a protein supplement in enset corm supplementation, because the farmer used feeding wheat bran in the locality.

Table .2. Experimental supplementary diets

\begin{tabular}{llll}
\hline Treatments & Basal diet & Supplement diets & Replication $^{\#}$ \\
\hline T1 & Harvested fresh natural grass ad labium & Enset corm + wheat bran & 8 \\
T2 & Harvested fresh natural grass ad labium & Sole wheat bran & 8 \\
T3 & Harvested fresh natural grass ad labium & Concentrate mix & 8 \\
\hline
\end{tabular}

$* N B: T 1=$ chopped enset corm $6 \mathrm{~kg}+1.5 \mathrm{~kg}$ wheat bran per day $/ \mathrm{cow}, \mathrm{T2}=3 \mathrm{~kg}$ sole wheat bran and $\mathrm{T3}=3 \mathrm{~kg}$ Concentrate mix /day/cow comprised of noug seed cake $33 \%+66 \%$ wheat bran and $1 \%$ salt .

The three treatment diets were applied to the selected twenty four cross breed dairy cows 6 cows within the same village two replication per village and 4 replication per district (uniform farm management). The treatment was given randomly to the experimental dairy cows.

\subsection{Measurements}

After one week adaptation period supplemented feed offered and supplement feed refusal was measured by using weighing machine and daily recorded. There was no any supplemented feed refusal through the experimental time. The daily average feed intake was estimated by the difference between the amounts of feed offered less the amount of feed refused during all the study period on DM basis.

\subsection{Milk yield}

Milking was done after calves suckle for about 1 minute. Cows were hand-milked twice a day starting at 5:00 am in the morning and 5:00 pm in the evening. The daily milk yield of individual cows was measured by farmers 
using a graduated plastic jug or they use bottle and measured by a liter and recorded. Average milk yield presupplementation (initial milk yield per cow per day per treatment), post supplementation (final milk yield/day/ cow/day per treatment) and average milk yield difference was the difference of daily milk increment per cow/ treatment) with in the 30 days of the study time was measured and recorded.

\subsection{Body weight:}

Body weights of the cows was measured at the initial and final time of the feeding period of one month by using heart girth meter that indicate the weight of the cross breed dairy cow.

\subsection{Chemical analysis of the feed samples}

The DM content of feed offered and refusal was determined by the standard methods of the Association of Official Analytical Chemists ( AOAC, 1990) and ash was determined by igniting the sample in muffles furnace at $5500 \mathrm{C}$ for $3 \mathrm{hrs}(\mathrm{AOAC}, 1990)$. Total nitrogen $(\mathrm{N})$ content of the feed was determined using Micro-Kjeldahl method. The crude protein content was calculated as $\mathrm{N}^{*}$ 6.25. Acid Detergent Fiber (ADF) and Neutral Detergent Fiber (NDF) content were determined according to Van Soest et al. (1991) using in an ANKOM® 200 Fiber Analyzer (ANKOM Technology Corp., Fairport, NY, USA). The feed chemical composition analysis was done at Hawassa Agricultural Campus animal nutrition laboratory.

\subsection{Partial budget analysis:}

Partial budget analysis has been conducted based on calculation of the total cost of supplement feeds and considering milk sales price. The milk price was fixed based on the milk price birr per liter paid to farmers in the locality. The price of the supplemented feed ingredients used was obtained from the current market price during the experimental period.(one medium enset corm 30 birr, one $\mathrm{kg}$ of wheat bran 5 birr and one $\mathrm{kg}$ of concentrate mix 5.75) Partial budget analysis were been employed to compute total cost of production/cow/day, mean milk yield/cow/day, price of milk/cow/day, cost of production/liter of milk, return/cow/day and net return/cow/day. The partial budget analysis was employed using the procedure of Upton (1979). The purchasing price of the supplemented feed and selling price of daily milk yield during the experimental period of time was considered as total return (TR) in the analysis. The net income (NI) was calculated by subtracting total variable cost (TVC) from the total return (TR). NI $=$ TR-TVC Marginal revenue MR $=$ NI / TVC.

\subsection{Data analysis}

Data on feed intake and milk yield were analyzed using the General Linear model (GLM) procedure of the statistical analysis system (SPSS). Duncan Multiple Range test was used for comparison of mean differences between treatments.

The model used for data analysis was

Yijkl $=\mu+\mathrm{Bi}+\mathrm{Mj}+\mathrm{Tk}+$ Eijkl (nutrient intake, milk yield and body weight) Where; $\mu=$ overall mean; $\mathrm{Bi}=$ body weight effect; $\mathrm{Mj}$ = milk yield; $\mathrm{Tk}$ = treatment effect; Eijkl = random error

Results were presented as least square means with their standard errors of mean SEM.

\section{Result and discussion}

3.1. Chemical Composition of Experimental Feed

Table 3: Chemical compositions of experimental feed and treatment diets

\begin{tabular}{|c|c|c|c|c|c|c|c|c|}
\hline \multirow{2}{*}{$\begin{array}{l}\text { Feed } \\
\text { Items }\end{array}$} & \multicolumn{8}{|c|}{ Nutrients } \\
\hline & DM\% & OM $\%$ & $\mathrm{CP} \%$ & NDF\% & ADF\% & $\begin{array}{l}\mathrm{Ca}: \\
\mathrm{g} / \mathrm{kg}\end{array}$ & $\begin{array}{c}\mathrm{P}: \\
\mathrm{g} / \mathrm{kg}\end{array}$ & $\mathrm{ME} \mathrm{cal} / \mathrm{kg}$ \\
\hline $\mathrm{T} 1$ & 22.70 & 18.10 & 3.5 . & 46.40 & 6.90 & 2.2 & 19.6 & $17.1 \mathrm{mj} / \mathrm{kg}$ \\
\hline $\mathrm{T} 2$ & 89.14 & 94.48 & 17.31 & 48.64 & 15.10 & 0.10 & 1.16 & \\
\hline T3 & 93.62 & 93.83 & 19.62 & 39.27 & 32.42 & 0.34 & 1.16 & 2.44 \\
\hline
\end{tabular}

*NB: enset corm, (T1),( AjebuN, 2008a), wheat bran (T2) Concentrate mix comprised of noug seed cake $33 \%, 66 \%$ wheat bran and $1 \%$ salt (T3). DM= Dry matter, $C P=$ Crude protein, $N D F=$ Nutral detergent fiber, $A D F=$ Acid detergent fiber. Laboratory analysis was worked at Hawassa University Animal Nutrition Laboratory Result

The chemical composition of the enset corn and wheat bran T1 and T2 the two treatment diets concentrate mix and sole wheat bran was observed. There was significant difference in the DM and OM content of the supplemented feed. However, there was lower CP content in enset corm supplementation T1 than T2 sole wheat bran and concentrate mix T3. Fiber analysis indicates that higher concentration of NDF (48.64) in T2 sole wheat bran and (46.40) in ensete corm followed by concentrate mix T3 (39.27) respectively and lower ADF (6.90) was obtained in enset corm.

\subsection{Nutrient intake of Experimental animals}


Table 4: The mean daily nutrients intakes of supplemented feed on Holstein Frisian cross bred dairy cow fed, ensetcorm, wheat bran and concentrate mixture per day per cow.

\begin{tabular}{lllll}
\hline Nutrient intake & \multicolumn{3}{c}{ Treatments } & \multirow{2}{*}{ Sig. } \\
\cline { 2 - 5 } In kg per day & $\mathrm{T} 1$ & $\mathrm{~T} 2$ & $\mathrm{~T} 3$ & $\mathrm{NS}$ \\
\hline DM intake & 2.7 & 2.67 & 2.81 & NS \\
OM intake & 1.5 & 2.53 & 2.64 & $*$ \\
CP intake & 0.28 & 0.46 & 0.55 & NS \\
NDF intake & 1.28 & 1.30 & 1.10 & $*$ \\
ADF intake & 0.29 & 0.40 & 0.91 & $*$ \\
\hline
\end{tabular}

$\mathrm{NB}^{*} \mathrm{T1}=6 \mathrm{~kg}$ of fresh enset corm with $1.5 \mathrm{~kg}$ of wheat bran, T2=3 $\mathrm{kg}$ of sole wheat bran, $\mathrm{T3}=3 \mathrm{~kg}$ of concentrate mix supplemented in DM basis.

The average voluntary nutrient intake of the experimental dairy cow fed on three different treatment diets given above in the Table3. The Dry matter intake of the supplemented treatment diet (DMI) in T3 (2.81 $\mathrm{kg} /$ day/cow $)$ and T2 (2.67kg/day/cow) and T1 (2.7 kg/day /cow) has no significant differences $(\mathrm{P}>0.05)$ among the three treatments. However, there was significantly difference $(p<0.05)$ on CP intake among the treatments. There was significant difference $(\mathrm{P}<0.05)$ in $\mathrm{ADF}$ intake among the four treatments. The low OM intake recorded in cows supplemented with enset corm mix with wheat bran.

\subsection{Milk yield of the experimental dairy cows}

Table. 5. Average milk production per cow per day in different villages for one month

\begin{tabular}{lrrrr}
\hline Daily Milk yield & \multicolumn{3}{c}{ Treatments } \\
\cline { 2 - 5 } In one month & $\mathrm{T} 1$ & $\mathrm{~T} 2$ & $\mathrm{~T} 3$ & Sig. \\
\hline $\begin{array}{l}\text { Average milk yield } \\
\text { *Pre- treatment(lit/ 30days) }\end{array}$ & $3.85 \pm 0.53$ & $3.93 \pm 0.50$ & $5.27 \pm 0.50$ & $\mathrm{NS}$ \\
$\begin{array}{l}\text { Average milk yield } \\
\text { *Post - treatment(lit/30 days) }\end{array}$ & $5.64 \pm 0.41$ & $5.43 \pm 0.39$ & $7.37 \pm 0.39$ & $*$ \\
$\begin{array}{l}\text { Average milk yield increased (lit/30 days ) } \\
\text { Percentage milk increased over per treatment/30 days }\end{array}$ & $1.92 \pm 0.40$ & $1.50 \pm 0.37$ & $2.10 \pm 0.37$ & $*$ \\
\hline
\end{tabular}

$\mathrm{NB}^{*} \mathrm{T1}=6 \mathrm{~kg}$ of fresh enset corm with $1.5 \mathrm{~kg}$ of wheat bran, $T 2=3 \mathrm{~kg}$ of sole wheat bran, $\mathrm{T3}=3 \mathrm{~kg}$ of concentrate mix supplemented in DM basis.

The effect of dietary treatment supplementation on milk yield of cross breed dairy cows is shown in Table 4. The results showed that, milk yield was significantly affected $(\mathrm{P}<0.05)$ by the type of nutrient supplement.T3 concentrate mixture $>\mathrm{T} 1$ composed of enset corm with wheat bran $>$ sole wheat bran. Average daily milk yield increment T3, 2.1liter per day per cow, T2, 1.50liter per day per cow, T1 1.92 lit per day per cow. Total daily milk yield was significantly different in $\mathrm{T} 3(2.1$ liter per day per cow $)(\mathrm{P}<0.05)$ and $\mathrm{T} 1(1.5$ liter/day/cow $)$ supplementing

Fig 2 . Average milk yield difference among 4 weeks of supplementation

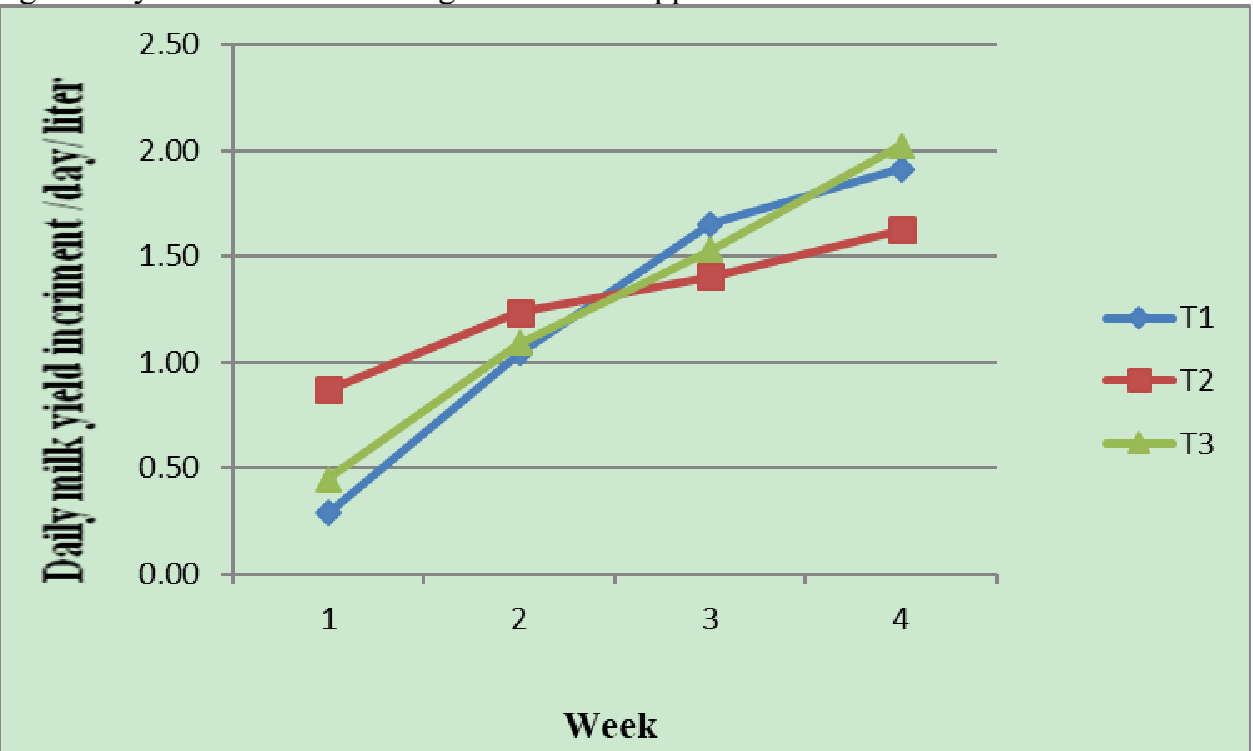

$N B^{*} T 1=6 \mathrm{~kg}$ of fresh enset corm with $1.5 \mathrm{~kg}$ of wheat bran, T2=3 $\mathrm{kg}$ of sole wheat bran, T3= $3 \mathrm{~kg}$ of concentrate mix supplemented in DM basis. 
Table 6 . Body weight gain data among treatments in 4 weeks of supplementation of cross breed dairy cow at mid lactation period

\begin{tabular}{lllll}
\hline Body weight & \multicolumn{3}{c}{ Treatments } & Sig \\
\cline { 2 - 5 } & \multicolumn{1}{c}{ T1 } & \multicolumn{1}{c}{ T2 } & \multicolumn{1}{c}{ T3 } \\
\hline Initial weight $(\mathrm{kg})$ & $242.85 \pm 5.56$ & $236.50 \pm 5.20$ & $252.00 \pm 5.20$ & NS \\
Final weight $(\mathrm{kg})$ & $242.75 \pm 5.03$ & $236.25 \pm 5.03$ & $252.62 \pm 5.03$ & NS \\
Total gain $(\mathrm{kg})$ & $1.50 \pm 0.56$ & $1.50 \pm 0.56$ & $0.875 \pm 0.56$ & $\mathrm{NS}$
\end{tabular}

$N B^{*} T 1=6 \mathrm{~kg}$ of fresh enset corm with $1.5 \mathrm{~kg}$ of wheat bran, $T 2=3 \mathrm{~kg}$ of sole wheat bran, $T 3=3 \mathrm{~kg}$ of concentrate mix supplemented in DM basis.

In this study there was no significant difference $(\mathrm{P}>0.05)$ in body weight gain among the three supplement diets on the experimental cross breed dairy cow.

\subsection{Partial budget analysis}

Table 7: Partial budget analysis on daily milk yield difference of cross breed dairy cow fed a basal diet of natural grass; supplemented with enset corm with wheat bran, sole wheat bran and concentrate mixtures

Parameters

T1 Treatments

Average milk yield Pre- treatment(lit/30 days)

Average milk yield Post - treatment(lit/30 days)

Average milk yield increased (lit/30 days )

Cost of milk per liter (ETB)

Initial monthly average milk yield cost (ETB)

Final average monthly milk yield cost (ETB)

A. Total gross income(ETB)

Total income difference in a month (ETB)

Feed cost

Total Cost of the supplement in a month ETB

B. Total input cost(ETB

Gross profit (A-B)

T2

3.86

5.79

3.94

T3

1.93

18

$2,084.40$

5.44

1.50

18

$3,045.60$

$2,127.60$

$2,937.60$

1042.20

810

Marginal revenue $(\mathrm{A} / \mathrm{B})$

513.75

450

517.50

$N B^{*} T 1=6 \mathrm{~kg}$ of fresh enset corm with $1.5 \mathrm{~kg}$ of wheat bran, $T 2=3 \mathrm{~kg}$ of sole wheat bran, $T 3=3 \mathrm{~kg}$ of concentrate mix supplemented in DM basis.

In this study the partial budget analysis showed that (Table7) alternative dairy rations formulated from locally available feed ingredients and agro industrial by products was supplemented in mid lactation dairy cow, supplementation seems to be economically meaningful for crossbred dairy cows at smallholding farmers: a greater increase was observed for income from milk sales as compared to farmers practice sole wheat bran. In this study supplementation was gain profit in ( $\mathrm{T} 3=615.50$ birr per month) and $(\mathrm{T} 1=528.45$ birr per month) than T2 (360 birr per month) was observed. Using crossbred cows supplemented with sole wheat bran (T2)as farmers practice in the area compared with $\mathrm{T} 2$, enset corm added with wheat bran T2 and T3 concentrate mix. The net return from the three supplemented diets were higher in $\mathrm{T} 3>\mathrm{T} 1>\mathrm{T} 2$.

\section{Conclusions and Recommendation}

The present study revealed that there was significant difference in total daily milk yield at mid lactation stage of cross breed dairy cow supplemented withT1, fresh chopped $6 \mathrm{~kg}$ enset corm mixed with $1.5 \mathrm{~kg}$ of wheat bran, $\mathrm{T} 2$, $3 \mathrm{~kg}$ of sole wheat bran and T3, $3 \mathrm{~kg}$ of concentrate mix a basal diet of natural grass exerts an overall positive effect on nutrient intake and milk production. However, concentrate mix and enset corm with wheat bran was better performing than the sole wheat bran from the experimental treatments diets. Supplementation of dry season roughages with locally available fresh $6 \mathrm{~kg}$ enset corm with $1.5 \mathrm{~kg}$ of wheat bran or $3 \mathrm{~kg}$ concentrate mix is likely similar result in a greater response in milk yield of crossbred cows at the study area. It could be recommended, that a better strategy to improve the milk yield at mid lactation period of Holstein Frisian cross breed dairy cow under small hold farmers management condition supplementation with locally available $6 \mathrm{~kg}$ fresh enset (Ensete Ventricosum)) corm and $1.5 \mathrm{~kg}$ wheat bran was economically feasible at enset production area.

\section{Acknowledgements}

The authors would like to express their gratitude to all who have assisted and supported this study, particularly (SARI) Southern Agricultural Research Institute and Hawassa agricultural research center, LIVES project for the donation of the research fund, on the research time monitoring and evaluation the work at farmers level and reviewing the research work, during the planning phase of the experiment deserves great appreciation. Staff 
members at Arbegona and Bensa Woreda Livestock and fishery office and the four village livestock development agents are gratefully acknowledged for their permanent assistance in data collection and overall support.

\section{Reference}

Adugna Tolera. 2008. Feed resources and feeding management: A manual for feed operators and development workers. Ethiopia Sanitary and Phytosanitary Standards and Livestock and Meat marketing Program (SPSLMM). Addis Ababa, Ethiopia. p.38.

Ajebu N .(2008)Evaluation of the Nutritive Value of Enset (Ensete Ventricosum) as Livestock Feed in Southern Ethiopia

Ajebu Nurfeta, Adugna Tolera, Eik, LO and Sundstøl, F. 2008a. Chemical composition and in sacco dry matter degradability of different morphological fractions of 10 enset (Ensete ventricosum) varieties. Anim. Feed. Sci. Technol. 146: 55-73.

Ajebu Nurfeta, Adugna Tolera, Eik, LO and Sundstøl, F. 2008b. The supplementary value of different parts of enset (Ensete ventricosum) to sheep fed wheat straw and Desmodium intortum hay. Lives Sci. 119: 22-30.

Ajebu Nurfeta, Adugna Tolera, Eik, LO and Sundstøl, F. 2008c. Yield and mineral content of ten enset (Ensete ventricosum) varieties. Trop. Anim. Health Prod., 40: 299-309.

ARC (Agricultural Research Council), 1990. The nutrient requirement of ruminant livestock.Common Wealth Agricultural Bureaux. Slough, England. UK.

Azage, T., Birhanu, G., Hoekstra, D., 2006. Input supply system and services for market-orientedlivestock production in Ethiopia. In: Dessie, T.(Ed.), Proceedings of the 14th AnnualConference of Ethiopian Society of Animal Production (ESAP), held in Addis Ababa,Ethiopia, pp. 1-19.

Belete, A., Azage, T., Fekadu, B., Berhanu G., 2009. Fluid milk and butter production andmarketing systems in Fogera district, Amhara Region, Ethiopia. Conference on Biophysicaland Socio-economic Frame Conditions for the Sustainable Management of Natural resources.University of Hamburg, October 6-8, 2009 (www.tropentag.de/2009/abstracts/full/326.pdf).

CSA, 20010/11. Agricultural sample survey 2010/2011. Vol. II. Report on livestock and livestock characteristics. Statistical Bulletin. Addis Ababa, Ethiopia:

CSAELDMPS (Ethiopia Livestock Development Master Plan Study) (2007). Livestock DevelopmentMaster Plan Study, Volume 1-Dairy. Phase 1 Report- Data collection and Analysis.Government of Ethiopia Ministry of Agriculture and Rural Development. (www.igaddata.org/index.php).

FAOSTAT (Food and Agriculture Organization Statistics) (2010). FAOSTAT Livestock primary,cow whole milk production.

SAS (Statistical Analysis System) 2002 SAS Version 9.1.3. SAS Institute Inc., Cary, NC, USA.

Teshome, D. (2009). On-farm evaluation of urea treated rice straw and rice bran supplementation

on fed intake, milk yield and composition of Fogera cows, north western Ethiopia. MScThesis, Bahir Dar University, Bahir Dar, Ethiopia.

Tilahun, A., Solomon, M., Ralph, R. (2005). Identification of livestock feed production in Ethiopianhighlands: Potential and Experiences of the African Highlands Initiative; Presented at the $19^{\text {th }}$ Ethiopian Veterinary Association (EVA) Annual conference, 8 June 2005, Addis Ababa,Ethiopia.

UNECA (United Nations Economic Commission for Africa), 1997. Livestockdevelopment in Tigray: forage development strategy as a major entry point towards asustainable minimum grazing system, Part I. Sustainable Development andEnvironmental Rehabilitation Program (SAERP), UNECA, Addis Ababa. 